NBER WORKING PAPER SERIES

\title{
HOUSEHOLD DEBT OVERHANG DID HARDLY CAUSE A LARGER SPENDING FALL DURING THE FINANCIAL CRISIS IN AUSTRALIA
}

\author{
Lars E.O. Svensson \\ Working Paper 28776 \\ http://www.nber.org/papers/w28776 \\ NATIONAL BUREAU OF ECONOMIC RESEARCH \\ 1050 Massachusetts Avenue \\ Cambridge, MA 02138 \\ May 2021
}

I have benefitted from comments from or discussions with Johan Almenberg, Asger Andersen, Claes Bäckman, Benjamin Beckers, Robert Boije, Peter Englund, Gianni La Cava, David Norman, and Roine Vestman. I am especially grateful to Benjamin Beckers, who has kindly provided code for regressions on the HILDA dataset, and to the Australian Data Archive, which has granted me access to the dataset of the General Release of the HILDA survey. Support from the Jan Wallander and Tom Hedelius research foundation and the Tore Browaldh research foundation is gratefully acknowledged. The findings and views based on the HILDA data used in the paper should not be attributed to either the Australian Government Department of Social Services (DSS) or the Melbourne Institute of Applied Economic and Social Research (Melbourne Institute). Views expressed and any errors are my own. The views expressed herein are those of the author and do not necessarily reflect the views of the National Bureau of Economic Research.

NBER working papers are circulated for discussion and comment purposes. They have not been peer-reviewed or been subject to the review by the NBER Board of Directors that accompanies official NBER publications.

(C) 2021 by Lars E.O. Svensson. All rights reserved. Short sections of text, not to exceed two paragraphs, may be quoted without explicit permission provided that full credit, including () notice, is given to the source. 
Household Debt Overhang Did Hardly Cause a Larger Spending Fall during the Financial

Crisis in Australia

Lars E.O. Svensson

NBER Working Paper No. 28776

May 2021

JEL No. E21,G01,G18,G21,R21

\begin{abstract}
The "debt-overhang hypothesis" - that households cut back more on their spending in a crisis when they have higher levels of outstanding mortgage debt (Dynan, 2012) - seems to be taken for granted by macroprudential authorities in several countries in their policy decisions, as well as by the international organizations that evaluate and comment on countries' macroprudential policy. New results for Australian microdata are presented that reject the debt-overhang hypothesis. The results instead support the "spending-normalization hypothesis" of Andersen, Duus, and Jensen (2016), what can also be called the "debt-financed overspending" hypothesis - that the correlation between high pre-crisis household indebtedness and subsequent spending falls during the crisis reflects high debt-financed spending pre-crisis and a return to normal spending during the crisis. As discussed in Svensson $(2019,2020)$, this is consistent with the above correlation reflecting debt-financed overspending through what Muellbauer (2012) calls the "housingcollateral household demand" channel and Mian and Sufi (2018) the "credit-driven household demand" channel.
\end{abstract}

Lars E.O. Svensson

Department of Economics

Stockholm School of Economics

P.O. Box 6501

SE-11383 Stockholm

Sweden

and NBER

Leosven@gmail.com 


\section{Contents}

1 Introduction $\quad 1$

2 The simplest model of debt-financed overconsumption through the housingcollateral channel

3 The Andersen et al. (2016) results for Danish microdata $\quad 8$

4 New results for Australian microdata 11

4.1 The main result . . . . . . . . . . . . . . . . . . . . . 11

4.2 The spending-normalization hypothesis for other years . . . . . . . . . 11

4.3 Interaction between high debt levels and changes . . . . . . . . . . . . . 12

5 Relation to the results of Price, Beckers, and La Cava (2019) 14

5.1 The marginal propensity to spend out of a higher debt level . . . . . . . 16

6 Conclusion $\quad 17$

$\begin{array}{lr}\text { References } & 18\end{array}$

$\begin{array}{lr}\text { Appendix } & 22\end{array}$

A Amortization $\quad 22$ 


\section{Introduction}

At the micro level, several papers - including Mian and Sufi (2010) and Dynan (2012) for the US, Andersen, Duus, and Jensen (2016) (ADJ) for Denmark, and Bunn and Rostom (2014, 2015) for the UK - have established a correlation between the level of household indebtedness before the Global Financial Crisis and consumption spending cuts during the crisis. But, as emphasized by ADJ, the mechanism behind this correlation has not been well understood. A common interpretation is indeed that the correlation reflects a negative causal impact of pre-crisis household indebtedness on spending cuts during the crisis, what can be called the "debt-overhang hypothesis" (Dynan, 2012). ADJ calls this interpretation the "household balance-sheet hypothesis." One potential mechanism behind such a causal effect is that households having high levels of debt prior to the crisis were suddenly facing binding borrowing constraints when the crisis broke out and therefore cut spending. Another is that the housing-wealth loss due to falling housing prices and even finding themselves "underwater" induced highly indebted households to delever. A third is that highly levered households cut spending voluntarily due to precautionary motives.

The debt-overhang hypothesis seems to be taken for granted by macroprudential authorities in several countries, as well as by the international organizations that comment on countries' macroprudential policy. Here are two examples, from Finansinspektionen (the Swedish FSA) and the Bank of England: ${ }^{1}$

The risks associated with household debt are primarily related to the possibility that highly indebted households may sharply reduce their consumption in the event of a macroeconomic shock. This development was noted in other countries during the financial crisis in 2008-2009. If many households reduce their consumption at the same time, this can amplify an economic downturn. (Finansinspektionen, 2017 , p. 1)

$[\mathrm{H}]$ ighly indebted households are more likely to cut their consumption sharply to keep paying their mortgages, deepening the economic downturn. (Carney, 2020, p. 20)

However, ADJ emphasize that the correlation between pre-crisis indebtedness and subsequent spending cuts during the crisis could also reflect that the high debt level among some households was simply the result of high debt-financed spending in previous years, while the subsequent drop in spending reflected a return to normal levels. In this latter interpretation, the observed correlation does not reflect a causal effect from high debt on spending. ADJ (p. 99-100) refer to this mechanism as the "spending-normalization hypothesis." Thus, according to this hypothesis, some households decided to temporarily boost their spending

\footnotetext{
${ }^{1}$ See Svensson $(2019,2020)$ for examples from the international organizations.
} 
to high levels relative to their income before the crisis. Financed by borrowing, the high spending level pushed up pre-crisis debt-to-income ratios for these households. But since the spending boost was only temporary, spending subsequently dropped more for these households than for others, thus generating a negative correlation between pre-crisis indebtedness and spending growth during the crisis.

In examining the Danish microdata, ADJ first find a strong negative correlation between pre-crisis indebtedness of households and the change in spending during the crisis. Then they show that this reflects that highly indebted households spent a larger share of their income than their less-indebted peers prior to the crisis. During the crisis the spending share of their income fell back to a normal level. This is consistent with these households having borrowed in order to finance overspending relative to income pre-crisis, resulting in larger increases in debt for these households in these years. This borrowing and the overconsumption ceased during the crisis, and spending fell back to a normal level. In particular, once ADJ condition on the size of the pre-crisis change in debt, a high level of debt is no longer associated with a larger spending decline. Thus, they reject the debt-overhang hypothesis for Denmark and find support for their spending-normalization hypothesis.

A possible explanations to such a temporary increase in spending pre-crisis is a credit supply shocks, for example, through lower lending standards (Mian and Sufi, 2018). Suppose that some households used easy access to credit before the crisis to borrow large amounts for spending purposes, thus elevating their spending very much relative to their income. If these households were no longer able to borrow because of tighter credit restrictions after the crisis broke out, they would then have to reduce spending, prompting a large decline relative to the pre-crisis level. An alternative explanation centers on expectations for future income (Kaplan et al., 2019): Suppose some households had unusually optimistic expectations about future income growth. According to the life-cycle model, those households would have spent a higher fraction of their income than less optimistic households. But the fact that these households were unusually optimistic before the crisis may also imply that they lowered their expectations about future income more than others once the crisis hit, prompting a larger cut in spending. Another alternative explanation mentioned by ADJ is that the indebtednessspending correlation is related to the timing of purchases of large durable consumption goods, such as cars: Households that happened to buy a car in 2007 most likely saw a large upwards spike in spending in that year. If most of them realistically did not buy a car again within the next two years, the spike in spending was then followed by a large subsequent drop. If financed by borrowing, the car purchase would at the same time have implied a significant increase in debt in 2007 for these households. Under these circumstances, perhaps even random differences in the timing of purchase of large durables can potentially explain the 
observed correlation between pre-crisis leverage and weak subsequent spending growth. ${ }^{2}$

As an additional possible explanation, Svensson (2019, 2020) emphasizes debt-financed overspending through what Muellbauer (2012) calls the "housing-collateral consumption demand channel" and Mian and Sufi (2018) call the "credit-driven household demand channel." Through this channel, housing prices - or, more precisely, changes in housing prices - can affect household consumption. As housing prices rose before the crisis, many households increased their mortgages through housing-equity withdrawal (HEW) in order to finance overspending relative to their income. This showed up in a lower household saving rate. When the crisis hit and housing prices stopped rising and began to fall, further HEW was no longer possible. When the overspending ceased, spending fell back to a more normal level in relation to income and the saving rate rose. The housing-collateral channel-with HEW used for consumption - was not only operating in Denmark, Australia, and the UK before and during the crisis, but also in the US. ${ }^{3} 4$

For Australia, Price, Beckers, and La Cava (2019) (PBLC) provide an extensive and thorough exploration of the relationship between owner-occupier mortgage debt and the level of spending, using detailed HILDA panel microdata on households. They focus on the level of spending in more "normal" years, not on the fall in spending during the crisis years. In particular, they examine whether high levels of household debt causes a weaker level of spending, what they call a "debt-overhang effect" - to be distinguished from what is here called the debt-overhang hypothesis, which refers to the effect of high debt levels on the fall in spending during the crisis years, as in Mian and Sufi (2010) and Dynan (2012) for the US, ADJ for Denmark, Bunn and Rostom $(2014,2015)$ for the UK, and the present paper for Australia. PBLC do indeed find evidence of such a debt-overhang effect. They furthermore conclude that this debt-overhang effect is not driven by the spending-normalization hypothesis of ADJ. However, they do not test this hypothesis by running exactly the same regressions as ADJ have done. ${ }^{5}$

\footnotetext{
${ }^{2}$ ADJ (p. 113) separately examine whether the observed borrowing and spending pattern can be entirely explained by car purchases. They find that the share of households with large debt increases that purchased a new car in 2007 was much higher than for other households, but it was still only about 15 percent. For the remaining 85 percent of these households, something else than car purchases must have been behind the large increase in debt and subsequent drop in spending.

${ }^{3}$ As discussed in Price et al. (2019, appendix B), there are institutional features of the Australian mortgage market in the form of so-called offset or redraw facilites that most borrowers have attached to their mortgages. These make housing equity more liquid than otherwise and provide convenient ways to withdraw housing equity for spending purposes.

${ }^{4}$ As noted by Guren et al. (2019, p. 1): "In the mid-2000s boom and subsequent bust, housing wealth extraction through the mortgage market boosted consumption in the boom and reduced consumption in the bust (e.g., Mian and Sufi, 2011; Mian et al., 2013)."

${ }^{5}$ Kearns et al. (2020) provide a both broad and detailed analysis of the riskiness of Australian household debt, including stress tests of banks and households. One of their results is that "the household DTI ratio is a poor measure of the extent of risk [posed by Australian household debt]."
} 
The ADJ results thus reject the debt-overhang hypothesis for Denmark and support the spending-normalization/debt-financed overspending hypothesis. A most relevant question is whether or not the ADJ results hold for other countries.

In a companion paper to the present one, Svensson (2021) shows that the ADJ results hold also for UK microdata, so the debt-overhang hypothesis - and results in Bunn and Rostom (2015) - are rejected for these UK data, and the spending-normalization/debt-financed overspending hypothesis receives some support.

The present paper tests these hypotheses for the Australian HILDA microdata, using the same regressions as ADJ did. The ADJ results are confirmed for the Australian microdata. That is, the debt-overhang hypothesis is rejected for this data and the spendingnormalization/debt-financed overspending hypothesis is supported. The result is robust to an interaction effect and the variation in the base years allowed by the sample. To my knowledge, this is the first paper that explicitly tests these hypothesis with the ADJ method for microdata from other countries than Denmark.

The paper is outlined as follows. Section 2 presents the simplest possible model of debt-financed overconsumption through the housing-collateral channel. Section 3 reports the relevant ADJ results for the Danish microdata. Section 4 presents the new results for Australian microdata. Section 5 relates the results to those of Price et al. (2019). Section 6 presents some conclusions.

\section{The simplest model of debt-financed overconsump- tion through the housing-collateral channel}

In order to set up the simplest model of debt-financed overconsumption through the housingcollateral channel, consider a credit- and liquidity-constrained household with owner-occupied housing. Let it be a (wealthy) hand-to-mouth (HTM) household (Campbell and Mankiw, 1989; Kaplan et al., 2014; La Cava et al., 2016) with the the simple budget constraint

$$
C_{t}=\mathrm{EI}_{t}-i_{t} D_{t-1}+\Delta D_{t}
$$

where $C_{t}$ denotes nominal (non-housing) consumption (spending) during year $t, \mathrm{EI}_{t}$ denotes the household's (after-tax) earned income, $D_{t}$ denotes nominal mortgage debt held at the end of year $t, i_{t}$ denotes the (after-tax) nominal interest rate paid in year $t$ on nominal debt held at the end of year $t-1$, and $\Delta D_{t} \equiv D_{t}-D_{t-1}$ denotes the annual change in debt. The household does not receive any transfers, owns no assets except its housing, and has no liabilities except its mortgage debt. For simplicity, there is no operation and maintenance cost of housing, and thus no depreciation of the housing. (Appendix A generalizes the model slightly by including mandatory amortization.) 
The right-hand side of (2.1) is a measure of the household's cash-flow surplus available for consumption and saving, that is, earned income minus interest payments plus the debt increase. An HTM household uses all the available cash-flow surplus for (non-housing) consumption and does not save anything in cash or other liquid assets. The implicit assumption is that the household is credit- and liquidity-constrained to consume less than it would prefer. Its rate of time preference is higher than the interest rate, so the household would prefer to increase its current consumption by borrowing more, if it could.

By (2.1),

$$
\frac{\partial C_{t}}{\partial \Delta D_{t}}=1 \text { and } \frac{\partial C_{t}}{\partial D_{t-1}}=-i_{t}
$$

The marginal propensity to consume (MPC) out of a higher debt increase is positive and unity, whereas the MPC out of a higher (lagged) debt level is small and negative, because the interest rate is much smaller than unity. For an interest rate of $4 \%$, the magnitude of the MPC out of a higher debt increase is 25 times the magnitude of the MPC out of a higher debt level. ${ }^{6}$

Clearly, here variations in debt changes will have a much larger effect on fluctuations in current consumption than differences in the lagged debt level.

Assume that the household is subject to a loan-to-value constraint, if it wants to increase its debt,

$$
D_{t} \leq \alpha P_{t} \text { if } \Delta D_{t}>0 .
$$

Here $\alpha$ denotes the maximum LTV ratio (for example, 85\%) and $P_{t}$ denotes the nominal price of the household's housing in year $t$. Restricting the LTV constraint to apply only when debt is increased implies the realistic property of LTV constraints that the household does not have to reduce its debt if housing prices fall and cause the LTV constraint to be violated. (There are no margin calls for mortgage debt.)

Because the household is constrained to consume less than it would prefer, it takes out the maximum possible mortgage - maximizes HEW - each year. If the LTV constraint is not violated at an unchanged debt level, the household will borrow to make or keep the LTV constraint binding. If housing prices have fallen so as to cause the LTV constraint to be violated, the household will keep the debt level constant,

$$
D_{t}= \begin{cases}\alpha P_{t} & \text { if } D_{t-1} \leq \alpha P_{t}, \\ D_{t-1} & \text { if } D_{t-1}>\alpha P_{t} .\end{cases}
$$

\footnotetext{
${ }^{6}$ We can also see that $\partial C_{t} / \partial i_{t}=-D_{t-1}$. The consumption of highly-indebted HTM households is very sensitive to the interest rate. This is the cash-flow channel of monetary policy (La Cava et al., 2016; Flodén et al., 2018). It implies that highly indebted households with variable interest rates benefit from lower interest rates in crises. With flexible exchange rates and flexible inflation targeting, interest rates become low in recessions. Thus, high debt and variable interest rates provide indebted households with some insurance against bad times (Svensson, 2020, section 3.2).
} 
Suppose prices are - and have been - non-decreasing, $\Delta P_{t} \geq 0$, so the the household will keep the LTV constraint (2.3) binding, $D_{t}=\alpha P_{t}$. It then follows from (2.1) that

$$
C_{t}=\mathrm{EI}_{t}-\alpha i_{t} P_{t-1}+\alpha \Delta P_{t} \quad \text { if } \Delta P_{t-1} \geq 0 \text { and } \Delta P_{t} \geq 0
$$

Consumption will be very sensitive to changes in housing prices (as long as they are nondecreasing). This is an example of the housing-collateral household-demand channel with a binding LTV constraint. Thus, the housing-collateral channel is a channel through which housing prices affect consumption. ${ }^{7}$

The household's disposable income equals earned income plus capital income (which is negative here) plus imputed rental income from ownership of the housing. ${ }^{8}$ Introduce DIX ${ }_{t}$, disposable income excluding imputed rental income, which then equals earned income plus capital income,

$$
\mathrm{DIX}_{t}=\mathrm{EI}_{t}-i_{t} D_{t-1}
$$

Then the budget constraint can be written

$$
C_{t}=\mathrm{DIX}_{t}+\Delta D_{t}
$$

(Non-housing) consumption (spending) will equal DIX plus the change in debt.

Figure 2.1a shows an example in which earned income is constant and set at $110 .^{9}$ After having been constant at 440, housing prices start to grow at $4 \%$ per year after year 1 but stop growing and stay constant from year 10 onward. The rising housing prices allow the household to increase its mortgage through HEW while maintaining the LTV ratio at the cap of $85 \%$. Thereby it can increase its consumption substantially above DIX from year 2 . DIX is less than earned income by the interest payments. When debt rises, DIX falls further below earned income.

When prices stop growing, the household can no longer increase its mortgage and the debt-financed overconsumption relative to DIX has to stop. Consumption drops by $19 \%$ in year 11 and thereafter remains constant to just equal DIX, the earned income less interest on the debt. Because debt and thus interest payments are higher in year 11 than in years 1 and 2, consumption and DIX from year 11 onward is lower than in years 1 and 2. This reflects that $\partial C_{t} / D_{t-1}=-i_{t-1}=-0.04$.

\footnotetext{
${ }^{7}$ See Muellbauer (2012), Mian and Sufi (2018), and Svensson (2019, 2020) for further discussion of the housing-collateral/credit-driven household demand channel.

8 The imputed rental income from owner-occupied housing in year $t$ in theory equals the user cost of housing in year $t$. In the absence of any operation and maintenance cost and under the simplifying assumption that the cost of housing equity equals the mortgage interest rate, the user cost equals $\left[i_{t+1} P_{t}-(1-\tau) \Delta P_{t+1}\right] /\left(1+i_{t+1}\right)$, where $\tau$ is the (nominal) capital-gains tax on housing.

${ }^{9}$ The parameters and initial values are $\alpha=85 \%, P_{0}=P_{1}=440$, and $D_{0}=\alpha P_{0}=374$, and $\mathrm{EI}_{t}=110$ and $i_{t}=4 \%$ for $t \geq 0$.
} 
Figure 2.1: Housing prices, debt, LTV ratios, and consumption

a. Housing prices start to grow at $4 \%$ from year 1 but stay constant from year 10
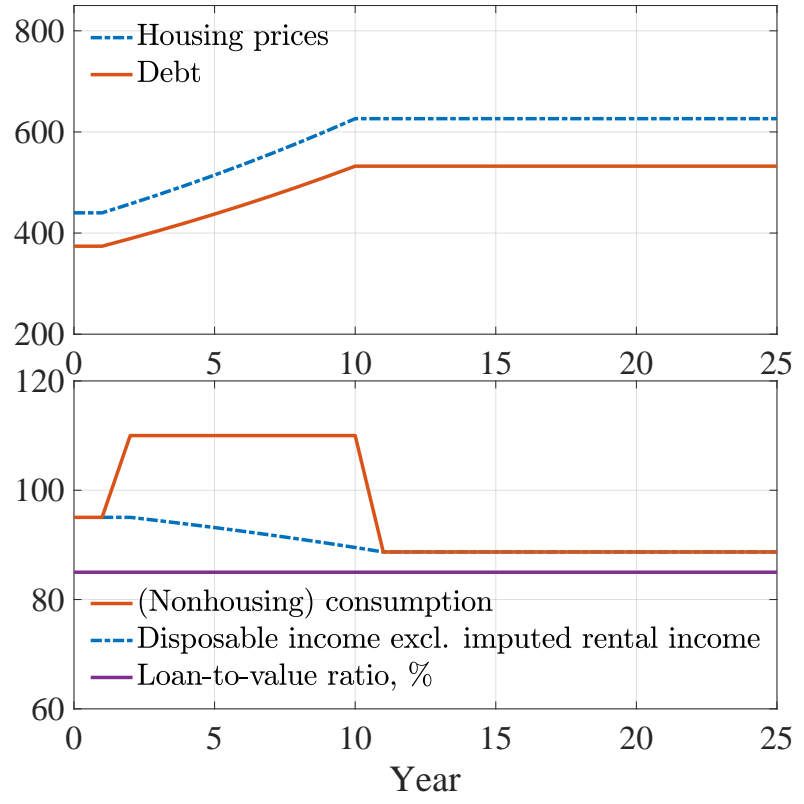

b. Housing prices start to grow at $4 \%$ from year 1 , except for a drop by $25 \%$ in year 11
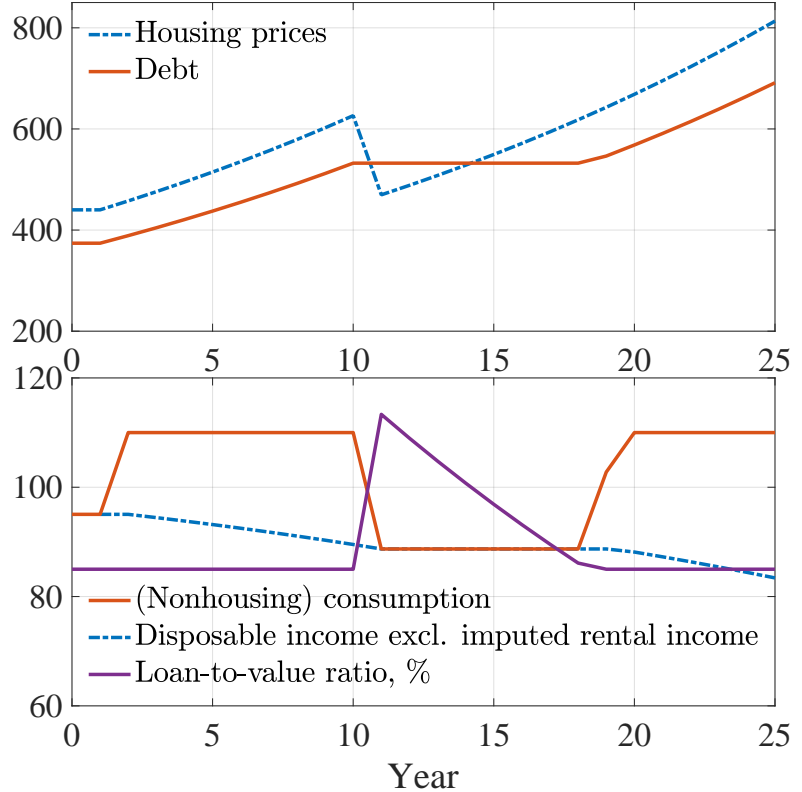

Figure 2.1b shows another example, in which housing prices also start to grow at $4 \%$ after year 1 but do not remain constant from year 10 onward. Instead they drop by $25 \%$ in year 11 and then resume to grow at 4\%. The drop in housing prices increases the LTV ratio from $85 \%$ to $113 \%$. This prevents further HEW, and consumption drops by $19 \%$. The rising housing prices reduce the LTV ratio back toward 85\% and in year 19 the household resumes HEW and debt-financed overconsumption relative to DIX.

In figures 2.1a and b, we can interpret year 11 as a crisis year and year 10 as a pre-crisis year. The consumption change from year 10 to year 11 is in these examples by (2.1) given by

$$
C_{11}-C_{10}=\Delta C_{11}=\Delta \mathrm{EI}_{11}-i \Delta D_{10}+\left(\Delta D_{11}-\Delta D_{10}\right)=-i \frac{g}{1+g} D_{10}-\Delta D_{10} .
$$

Here we use that $\mathrm{EI}_{t}$ and $i_{t}=i$ are constant; that $i \Delta D_{10}=i g D_{9}=i g D_{10} /(1+g)$, where $g$ is the constant growth rate of housing prices and debt up to year 10; and that $\Delta D_{11}=0$, because debt is constant after year 10 for several years.

With $i=4 \%$ and $g=4 \%$, on the right-hand side of (2.8) the coefficient of $D_{10}$ is only minus 0.0015 , whereas the coefficient on $\Delta D_{10}$ is minus 1 . So in these simple examples, the consumption fall during the "crisis" overwhelmingly depends on the pre-crisis debt increase, $\Delta D_{10}$, not on the pre-crisis debt level, $D_{10} \cdot{ }^{10}$ The pre-crisis debt level has a small increasing

\footnotetext{
${ }^{10}$ Appendix A shows that this result also holds when mandatory amortization is included.
} 
effect on the consumption fall due to the interest payments on the pre-crisis debt increase, $i \Delta D_{10}=i g D_{10} /(1+g){ }^{11}$

What causes the consumption fall in these examples? First, the credit- and liquidityconstrained HTM household desires to increase its consumption (its rate of time preference exceeds the after-tax mortgage interest rate). This implies a binding LTV constraint (when housing prices are non-decreasing). Second, a period of rising housing prices eases the LTV constraint and allows debt increases through HEW to finance a welcome overconsumption relative to the households disposable income. Third, an end to the period of rising housing prices prevent further HEW-financed overconsumption, which forces consumption to fall back to equal DIX (disposable income excluding imputed rental income). Thus, given the setup, the fall in consumption is caused by the stop in HEW, which in turn is caused by the end of the period of rising housing prices. The HEW during the period of rising housing prices is caused by the households desire to increase its consumption.

\section{The Andersen et al. (2016) results for Danish micro- data}

ADJ test the debt-overhang and spending-normalization/debt-financed overspending hypotheses on Danish microdata (registry data). The crucial regression is of the form

$$
\frac{C_{2009}^{h}-C_{2007}^{h}}{Y_{2007}^{h}}=\alpha+\delta_{1}\left(\frac{D_{2007}^{h}}{Y_{2007}^{h}}\right)^{\mathrm{High}}+\delta_{2}\left(\frac{D_{2007}^{h}-D_{2006}^{h}}{Y_{2007}^{h}}\right)^{\mathrm{High}}+\lambda \mathbf{X}_{2007}^{h}+\varepsilon^{h},
$$

where $C_{t}^{h}$ denotes (imputed) spending by household $h$ in year $t, Y_{t}^{h}$ denotes pre-tax income in year $t, D_{t}^{h}$ denotes total debt at the end of year $t$, and $\mathbf{X}_{t}^{h}$ is a vector of control variables containing a range of household characteristics as of year $t$. The expression $\left(Z_{t}^{h}\right)^{\text {High }}$ denotes a dummy for $Z_{t}^{h}$ exceeding its 75 th percentile in year $t .^{12}$

We note the similarity of (3.1) to (2.8). We also note that, by (2.8), any normalization by pre-tax income or any other variable in (3.1) should involve dividing the spending change on the left-hand side and the debt level and change on the right-hand side by the same variable, in this case pre-crisis pre-tax income.

${ }^{11}$ If we do not assume a constant interest rate, the term $i \Delta D_{10}$ is replaced by $i_{11} D_{10}-i_{10} D_{9}=i_{11} \Delta D_{10}+$ $\Delta i_{11} D_{9}$. This illustrates that a fall in the interest rate during the crisis, $\Delta i_{11}<0$, will for a large debt level through the fall in interest payments have a large dampening effect on the consumption fall of the HTM household (the cash-flow channel of monetary policy).

12 The registered-based data ADJ use do not include consumption or spending at the household level. They instead rely on a spending measure imputed on data from household disposable income, assets, and liabilities. In order to exclude capital gains on housing, they restrict the sample to households that have not bought or sold one or more homes during the sample. The sample still include close to 500,000 households (ADJ, section 3). 
According to the debt-overhang hypothesis, high indebtedness of a household in 2007 caused a larger drop in the household's spending from 2007 to 2009. A test of the hypothesis is then whether or not the estimate of the coefficient $\delta_{1}$ is negative as well as statistically and economically significant.

According to the spending-normalization/debt-financed overspending hypothesis, a larger fall in spending from 2007 to 2009 is due to overspending in 2007 financed by a high debt increase from 2006 to 2007. The hypothesis then implies that the fall in spending is predicted by a high debt increase rather than by a high debt level in $2007 .{ }^{13}$ A test of the hypothesis is then whether - when the debt increase is included among the explanatory variables - the estimate of the coefficient $\delta_{2}$ is negative as well as economically and statistically significant, together with the estimate of $\delta_{1}$ being small and economically insignificant. Put differently, whether a regression with the debt level as regressor without the change in debt is subject to an omitted-variable problem.

Table 3.1: Regressions for Denmark of the change in imputed spending relative to income on high levels of and high changes in mortgage debt relative to income (Andersen et al., 2016, table 4)

Dependent variable: Change in imputed spending from 2007 to 2009 relative to pre-tax income in 2007

\begin{tabular}{|c|c|c|c|c|c|}
\hline \multirow[b]{2}{*}{ Variables } & \multirow[t]{2}{*}{ (1) } & \multirow{2}{*}{\multicolumn{2}{|c|}{$\begin{array}{c}(2) \\
\text { Change from } 2006 \text { to } 2007\end{array}$}} & \multirow{2}{*}{\multicolumn{2}{|c|}{$\begin{array}{cc}(6) & (7) \\
\text { Change from } 2003 \text { to } 2007\end{array}$}} \\
\hline & & & & & \\
\hline$\left(\frac{D_{2007}^{h}}{Y^{h}}\right)^{\text {High }}$ & $-0.0448^{* * *}$ & & $0.0224^{* * *}$ & & $0.0211^{* * *}$ \\
\hline & $(0.0017)$ & & $(0.0017)$ & & $(0.0019)$ \\
\hline$\left(\frac{D_{2007}^{h}-D_{2006}^{h}}{Y_{2007}^{h}}\right)^{\mathrm{High}}$ & & $\begin{array}{c}-0.2601^{* * *} \\
(0.0016)\end{array}$ & $\begin{array}{c}-\mathbf{0 . 2 6 5 4} * * * \\
(0.0016)\end{array}$ & & \\
\hline$\left(\frac{D_{2007}^{h}-D_{2003}^{h}}{Y_{2007}^{h}}\right)^{\text {High }}$ & & & & $\begin{array}{c}-0.1267^{* * *} \\
(0.0016)\end{array}$ & $\begin{array}{c}-\mathbf{0 . 1 3 6 3} * * * \\
(0.0018)\end{array}$ \\
\hline Observations & 492,194 & 492,194 & 492,194 & 492,194 & 492,194 \\
\hline R-squared & 0.0488 & 0.0972 & 0.0976 & 0.0592 & 0.0594 \\
\hline
\end{tabular}

Source and note: See ADJ (table 4) for details. Columns are numbered as in ADJ, duplicate column (5) is excluded. A typo in table 4, column (2) is corrected; the crucial minus in front of the coefficient $0.2601^{* * *}$ is inserted. The expression $\left(Z^{h}\right)^{\text {High }}$ denotes a dummy for the variable $Z^{h}$ exceeding its 75 th percentile in 2007. The control variables (coefficients are not reported) include municipality, age of oldest member, number of children, no. of years since moving in, higher education, retirees, decile of income, decile of net wealth to income, and decile of liquid assets to income; all are measured in 2007. Standard errors in parenthesis. *, **, and $* * *$ denotes significance at the $5 \%, 1 \%$, and $0.1 \%$ level, respectively.

The main result is reported in ADJ (table 4), reproduced here as table 3.1. ${ }^{14}$ The result in

\footnotetext{
13 According to this hypothesis, it is an increase in spending intentions that leads to a debt increase to support consumption. That is, there is reverse causality. Therefore, the debt increase predicts rather than causes the fall in spending.

${ }^{14}$ Note that the second regressor in (3.1) refers to the change in debt from 2006 to 2007 divided by income in
} 
column (1) of the table, with the dummy for a high debt level as the only regressor (besides controls), gives some support for the debt-overhang hypothesis. However, in column (3), where the dummy for a high debt change is added as a regressor, the debt-overhang hypothesis is rejected and the spending-normalization/debt-financed overspending hypothesis is supported. The negative correlation between high pre-crisis debt and larger subsequent spending falls is entirely driven by the fact that a large share of the households with high debt-to income ratios in 2007 had increased their debt by large amounts for consumption purposes in the run-up to the crisis. The level of debt itself does not help to explain the larger spending decline for this group. Not including the change in debt among the explanatory variables thus results in a standard omitted-variable bias of the estimate of the coefficient on a high DTI ratio.

Columns (6) and (7) show that the same result occurs when the change in debt from 2003 to 2007 is substituted for the change from 2006 to 2007.

ADJ (p. 108) summarize the main result as,

within groups of households that experienced similar-sized changes in debt from 2006 to 2007, those with a high level of debt in 2007 did not reduce spending more from 2007 to 2009 than those with only little debt in 2007. But those that experienced a large increase in debt from 2006 to 2007 cut spending by more than those that did not experience a large increase, even if they had similar debt levels at the end of $2007 \ldots$. [T] he results are the same if we instead use the change in debt since 2003, rather than 2006.

Broadbent (2019) summarized the result as: ${ }^{15}$

Once you know the change in a household's indebtedness ahead of the crisis, knowing the level tells you nothing more about its subsequent spending.

Thus, the ADJ result rejects the debt-overhang hypothesis for Denmark and supports the spending-normalization/debt-financed overspending hypothesis. An important question is to what extent the ADJ result holds for other countries.

2007, not the change in the debt-to-income ratio from 2006 to 2007, as has been confirmed in correspondence with Asger Andersen. The heading/note to ADJ (table 4) causes some confusion by mistakenly referring to the change in the debt-to-income ratio, but the text of the paper is clear.

15 Broadbent (2019) provides an insightful discussion and several examples of why the level of household debt - at very different points of time, across countries, and even for individual households - is a poor predictor of subsequent financial distress, and why debt growth does better. 


\section{New results for Australian microdata}

\subsection{The main result}

Table 4.1 reports new regression results for Australian HILDA survey data (DSS and Melbourn Institute, 2018) using exactly the same regressions as in ADJ (table 4) and table 3.1. The results are qualitatively similar to the ADJ results for Denmark, except that in column (1) the small negative coefficient on a high debt ratio is not significant. Thus, the debt-overhang hypothesis does not receive any support from this regression alone. Furthermore, when a high change in debt is introduced as an explanatory variable in column (3), its coefficient is negative and significant at the $5 \%$ level (significant at the $10 \%$ level in column (7)), whereas the coefficient on the high debt is closer to zero and not signifiant. Thus, the debt-overhang hypothesis is rejected also for this Australia data, and the spendingnormalization/debt-financed overspending hypothesis is supported.

The estimated coefficients on debt changes for Australia are about a fifth of the ADJ estimates for Denmark. That they are smaller than for Denmark is plausible, because Australia was considerably less affected by the Global Financial Crisis. Unemployment only increased in early 2009 but quickly stabilized and was dampened by the mining investment boom. Housing prices only fell briefly and soon recovered. With most households having variable mortgage rates, cuts in the RBA policy rate reduced mortgage rates and eased households' budget constraints directly through the cash-flow channel of monetary policy (Reserve Bank of Australia, 2012; La Cava et al., 2016) (see also figure 5.1 below).

Are the coefficients still economically significant? The coefficient of -0.048 in column (3) implies that the $25 \%$ of households with the highest debt increases relative to income in 2007 cut their spending from 2007 to 2009 by on average $5 \%$ more of their pre-tax income than households with less debt increases. That seems economically significant.

\subsection{The spending-normalization hypothesis for other years}

ADJ refer to the regressions in table 3.1 on the change in spending from 2007 to 2009, divided by (pre-tax) income in 2007, as having the base year 2007. They also test the spending-normalization hypothesis for other base years than 2007, namely thus whether

the larger decline in spending among highly indebted households is the result of a spending-normalization pattern that is also found in other years than during the crises, rather than a causal effect of high debt levels suppressing household spending during the crisis. (ADJ, abstract)

ADJ (table 5, not shown here) show regression results that support the spending-normalization 
Table 4.1: Regressions for Australia of the change in spending relative to income on high levels of and high changes in mortgage debt relative to income

Dependent variable: Change in spending from 2007 to 2009 relative to pre-tax income in 2007

\begin{tabular}{|c|c|c|c|c|c|}
\hline \multirow[b]{2}{*}{ Variables } & \multirow[t]{2}{*}{ (1) } & $(2)$ & $(3)$ & (6) & (7) \\
\hline & & Change from & 2006 to 2007 & \multicolumn{2}{|c|}{ Change from 2003 to 2007} \\
\hline \multirow{2}{*}{$\left(\frac{D_{2007}^{h}}{Y_{2007}^{h}}\right)^{\text {High }}$} & -0.0122 & & -0.0028 & & 0.0116 \\
\hline & $(0.0222)$ & & $(0.0241)$ & & $(0.0295)$ \\
\hline \multirow{2}{*}{$\left(\frac{D_{2007}^{h}-D_{2006}^{h}}{Y_{2007}^{h}}\right)^{\mathrm{High}}$} & & $-0.0485^{* *}$ & $-0.0480^{* *}$ & & \\
\hline & & $(0.0206)$ & $(0.0210)$ & & \\
\hline \multirow{2}{*}{$\left(\frac{D_{2007}^{h}-D_{2003}^{h}}{Y_{2007}^{h}}\right)^{\text {High }}$} & & & & $-0.0442^{*}$ & $-0.0481^{*}$ \\
\hline & & & & $(0.0240)$ & $(0.0259)$ \\
\hline Observations & 1,757 & 1,570 & 1,570 & 1,279 & 1,279 \\
\hline R-squared & 0.118 & 0.140 & 0.140 & 0.158 & 0.158 \\
\hline
\end{tabular}

Source and note: DSS and Melbourn Institute (2018) and own regressions. Columns are numbered and dummies are defined as in table 3.1. Control variables include age of oldest member, number of children, no. of years since moving in, higher education, retirees, decile of income, decile of net housing wealth to income, and decile of liquid assets to income; all are measured in 2007 except 2006 for the decile of liquid assets to income. OLS. Standard errors in parenthesis. * ${ }^{* *}$, and ${ }^{* * *}$ denote significance at the $10 \%, 5 \%$, and $1 \%$ level, respectively.

hypothesis for not only the base year 2007, as in table 3.1, but also for all the base years 20032009.

Running the same regression as in ADJ on the Australian data for other base years than 2007 is constrained by the fact that durable spending and thereby total spending was only collected in the HILDA survey for the years 2006-2010. This means that it is only possible to run the regression for the additional base years 2006 and 2008. The results are reported in table 4.2, panels a and c. The results for base year 2006 (panel a) are very similar and even somewhat stronger than that for base year 2007 (panel b). The results for base year 2008 (panel c) is weaker than that for base year 2007. The p-values for the coefficients on high debt and high debt change in column (2) is $79 \%$ and $11 \%$, respectively, so the coefficient on the latter is close to significant at a $10 \%$ level.

There is certainly no support for the debt-overhang hypothesis. Overall, there is support for the spending-normalization hypothesis also for the year before and - to some extent - the year after the base year 2007.

\subsection{Interaction between high debt levels and changes}

ADJ do not include an interaction term between the debt change and the debt level. An implicit assumption is then that the effects of the debt change and the debt level are additive and independent. However, it might be the case that a household that increases its debt a 
Table 4.2: Regressions for Australia for several base years of the change in spending relative to income on high levels of and high changes in mortgage debt relative to income

Dependent variable: For base years 2006, 2007, and 2008, change in spending from the base year to the base year +2 , relative to pre-tax income in the base year

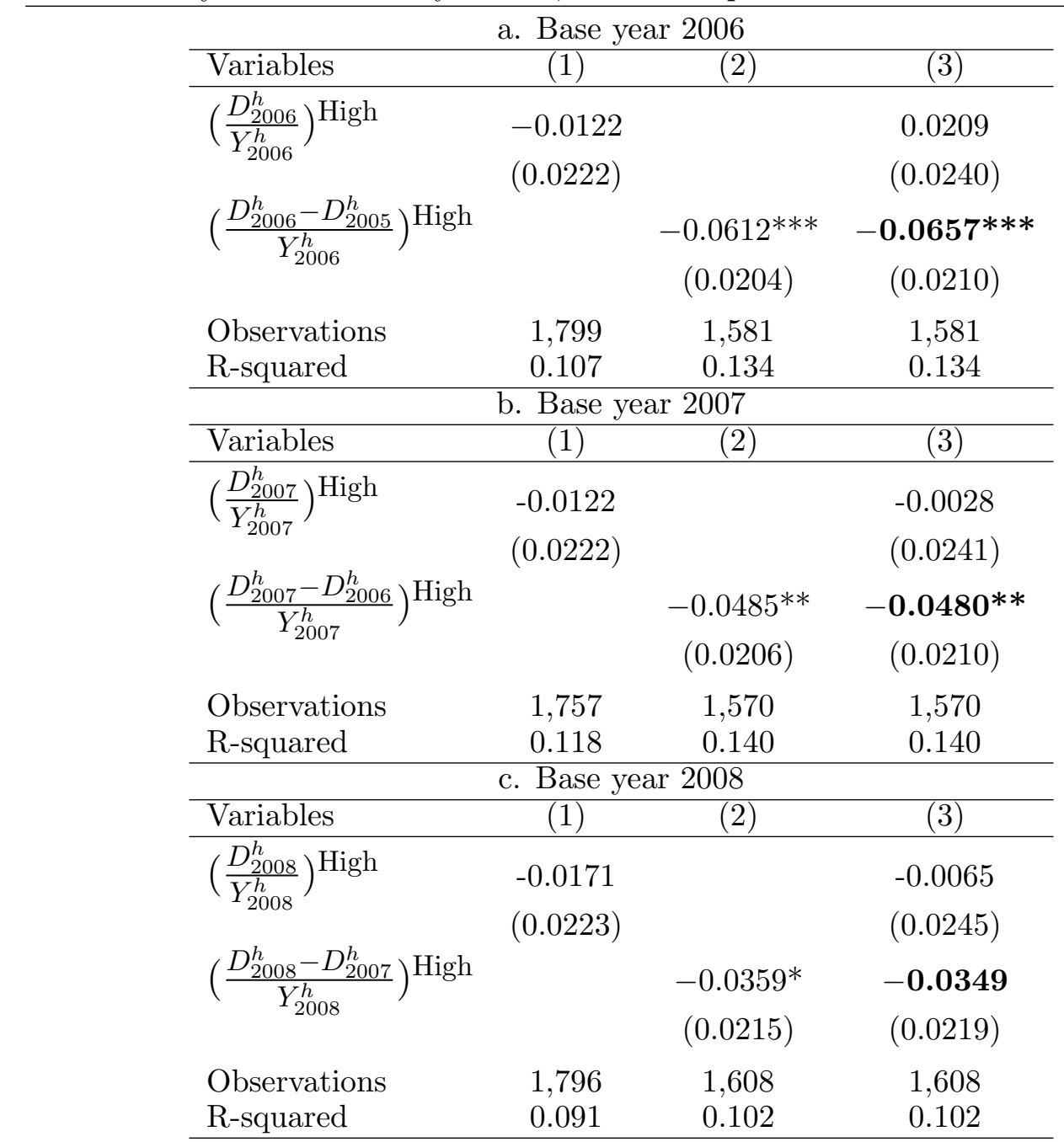

Source and note: DSS and Melbourn Institute (2018) and own regressions. Numbering of columns (1)-(3), definition of dummies, and control variables as in table 4.1. Panel b, columns (1)-(3), coincides with same columns of table 4.1. Control variables are all measured in the base year except the decile of liquid assets to income, which is measured in 2006. OLS. Standard errors in parenthesis. ${ }^{*},{ }^{* *}$, and ${ }^{* * *}$ denote significance at the $10 \%, 5 \%$, and $1 \%$ level, respectively.

lot to a high level would cut its spending more than if it had increased its debt a lot to a lower level.

Table 4.3, column (2) therefore examines the interaction of a high debt level and a high debt change, by adding a dummy for this. The rejection of the debt-overhang hypothesis and the support for the spending-normalization/debt-financed overspending hypothesis is robust to such an interaction. 
Table 4.3: Regressions for Australia of the change in spending relative to income on high levels of and high changes in mortgage debt relative to income as well as of their interaction Dependent variable: Change in spending from 2007 to 2009 relative to pre-tax income in 2007

\begin{tabular}{lcc}
\hline Variables & $(1)$ & $(2)$ \\
\hline$\left(\frac{D_{2007}^{h}}{Y_{2007}^{h}}\right)^{\text {High }}$ & -0.0028 & -0.0255 \\
& $(0.0241)$ & $(0.0310)$ \\
$\left(\frac{D_{2007}^{h}-D_{2006}^{h}}{Y_{2007}^{h}}\right)^{\text {High }}$ & $-\mathbf{0 . 0 4 8 0 * *}$ & $-\mathbf{0 . 0 6 5 2 * *}$ \\
$\left(\frac{D_{2007}^{h}}{Y_{2007}^{h}}\right)^{\text {High }}$ and $\left(\frac{D_{2007}^{h}-D_{2006}^{h}}{Y_{2007}^{h}}\right)^{\text {High }}$ & $(0.0210)$ & $(0.0257)$ \\
Observations & & 0.0514 \\
R-squared & 1,570 & $(0.0442)$ \\
\hline
\end{tabular}

Source and note: DSS and Melbourn Institute (2018) and own regressions. Dummies are defined as in table 3.1. Control variables include age of oldest member, number of children, no. of years since moving in, higher education, retirees, decile of income, decile of net housing wealth to income, and decile of liquid assets to income; all are measured in 2007 except 2006 for the decile of liquid assets to income. OLS. Standard errors in parenthesis. *, ${ }^{* *}$, and ${ }^{* * *}$ denote significance at the $10 \%, 5 \%$, and $1 \%$ level, respectively.

\section{Relation to the results of Price, Beckers, and La Cava (2019)}

The focus in the above analysis is whether or not high household debt indebtedness causes deeper downturns in crises and, more precisely, whether the data is consistent with the debtoverhang hypothesis or the spending-normalization/debt-financed overspending hypothesis best explaining the spending cuts during the crisis.

Price, Beckers, and La Cava (2019) (PBLC) provide an extensive and thorough exploration of the relationship between owner-occupier mortgage debt and the level of spending in Australia, using detailed HILDA panel data on households, with a different focus. They focus on the level of spending during more "normal" years, not on the fall in spending during the crisis years. In particular, they examine whether high levels of household debt causes a weaker level of spending, what they call a "debt-overhang effect". This is thus to be distinguished from the debt-overhang hypothesis, which refers to the effect of high debt levels on the fall in spending during the crisis years, as in Mian and Sufi (2010) and Dynan (2012) for the US, ADJ for Denmark, Bunn and Rostom (2014, 2015) for the UK, and the present paper for Australia.

PBLC do indeed find evidence of a debt-overhang effect for Australia. They furthermore conclude that this debt-overhang effect is not driven by the "spending-normalization hypothesis" of ADJ. 
Among several specifications, PBLC estimate a regression of the form

$$
C_{t}^{h}=\beta_{0}+\beta_{1} D_{t-1}^{h}+\beta_{2} Y_{t}^{h}+\beta_{3} A_{t-1}^{h}+\gamma \mathbf{X}_{t}^{h}+\delta^{h}+\varepsilon_{t}^{h},
$$

where $C_{t}^{h}$ denotes spending of household $h$ in year $t, D_{t-1}^{h}$ denotes the lagged level of owneroccupied mortgage debt, $Y_{t}^{h}$ denotes disposable income, sand $A_{t-1}^{h}$ denotes the lagged reported home value. The vector $\mathbf{X}_{t}^{h}$ denotes a set of control variables to summarize the other observed determinants of spending, including factors associated with a household's permanent income, such as age, education and labour force status. Furthermore, $\delta^{h}$ denotes a household fixed effect which captures household characteristics that determine spending but are plausibly invariant over time (for example, degree of impatience and risk aversion). The inverse hyperbolic sine (IHS) transformation are applied to the main variables of interest, to allow small, zero, or negative values. This means that estimated coefficients of the main variables of interest can be interpreted as approximate elasticities.

PBLC estimate several versions of (5.1), including OLS with and without the household fixed effect and an IV estimation without the fixed effect, and they conduct multiple robustness tests. Their preferred benchmark estimate of $\beta_{1}$ is -0.03 , significant at a $5 \%$ level, for an OLS fixed-effect estimation on the sample 2006-2010 with total spending (nondurable plus durable) as the dependent variable (their table 2, column 8). That is, the estimated (partial) elasticity of total spending with respect to lagged debt, which can be denoted $\varepsilon C_{t} / \varepsilon D_{t-1}$, is -0.03 .

PBLC also test the ADJ spending-normalization hypothesis, by adding $D_{t-1}^{h}-D_{t-2}^{h}$ as a regressor in (5.1). Because of the IHS transformation of the debt levels, this term can be interpreted as the lagged debt growth rate. The coefficient on the lagged debt growth rate is close to zero and not significant (PBLC, table 5, column (2)). The estimated elasticity of spending with respect to lagged debt is unchanged and equal to their benchmark estimate. They then conclude:

In contrast to Andersen et al. (2016), we find no evidence that... lagged changes in debt explain lower spending today. (p. 20)

However, PBLC run a different regression than ADJ have run, namely (5.1) with lagged debt growth added. This is also different from the model equation (2.8). As we have seen, running the same regression as in ADJ, (3.1), rejects the debt-overhang hypothesis and supports the spending-normalization/debt-financed overconsumption hypothesis (which hypotheses then refers to the dependent variable being the fall in spending during the crisis years, not the level of spending during more normal years). 


\subsection{The marginal propensity to spend out of a higher debt level}

Given the PBLC benchmark estimate of the elasticity of spending with respect to debt, $\varepsilon C_{t} / \varepsilon D_{t-1}=-0.03$, one can construct an approximate estimate of the aggregate marginal propensity to spend (MPC) out of a higher (lagged) debt level, $\partial C_{t} / \partial D_{t-1}$, by using the relation

$$
\frac{\partial C_{t}}{\partial D_{t-1}}=\frac{\varepsilon C_{t}}{\varepsilon D_{t-1}} \frac{C}{D}=-0.03 \frac{C}{D},
$$

where $C / D$ is the ratio between average household spending and average household mortgage debt.

PBLC state that, from 2006 to 2010, the ratio of annual spending for both indebted and non-indebted households to owner-occupied mortgage debt averages around 1.05. Using this in (5.2) results in an MPC of about $-0.03 \cdot 1.05=-3.2 \%$.

However, one could argue that the relevant ratio of spending to owner-occupied debt is that of indebted households, those with mortgage debt, thus excluding non-indebted households. ${ }^{16}$ PBLC (table C1, left column) reports annual total spending and mortgage debt during 2006-2010 for indebted households, from which the spending-to-debt ratio can be calculated to be

$$
\frac{C}{D}=\frac{\text { AUD } 50,346}{\text { AUD } 226,211}=\frac{1}{4.5} .
$$

It follows that the MPC out of a higher debt level for indebted households would be

$$
\frac{\partial C_{t}}{\partial D_{t-1}}=-\frac{0.03}{4.5}=-0.0067=-0.67 \% .
$$

This is arguably a rather small number. It may be instructive to compare with what MPC follows from the (wealthy) hand-to-mouth household discussed in section 2, which by (2.2) is given by $\partial C_{t} / \partial D_{t-1}=-i_{t}$, where $i_{t}$ is the mortgage interest rate paid in year $t$.

Figure 5.1 shows that Australian mortgage rates were on average about $7.5 \%$ during $2006-$ 2010, the sample period of PBLC, which might suggest a marginal propensity to spend out of a higher debt level for indebted HTM households of about $-7.5 \%$, an order of magnitude larger than the estimate $-0.67 \%$ in (5.4) and about double the PBLC estimate of $-3.2 \%$.

We furthermore see that mortgage rates fell quickly by 3.8 percentage points from a peak of $9.6 \%$ in August 2008 to a trough of $5.8 \%$ in April 2009. During this period, the Reserve Bank of Australia cut its policy rate, the cash rate, by 4.25 percentage points from $7.25 \%$ to $3 \%$. With the typical Australian mortgage having variable rates, this improved the cash flow of indebted households, which supported spending, in line with the Australian cash-flow channel of monetary policy. ${ }^{17}$

\footnotetext{
16 According to Australian Bureau of Statistics (2018), in 2015-16 only about a third of Australian households had mortgage debt.

${ }^{17}$ However, as discussed in detail in La Cava et al. (2016) and Price et al. (2019, appendix B), there are
} 
Figure 5.1: Lending rates for owner-occupier housing loans and Reserve Bank of Australia cash rate

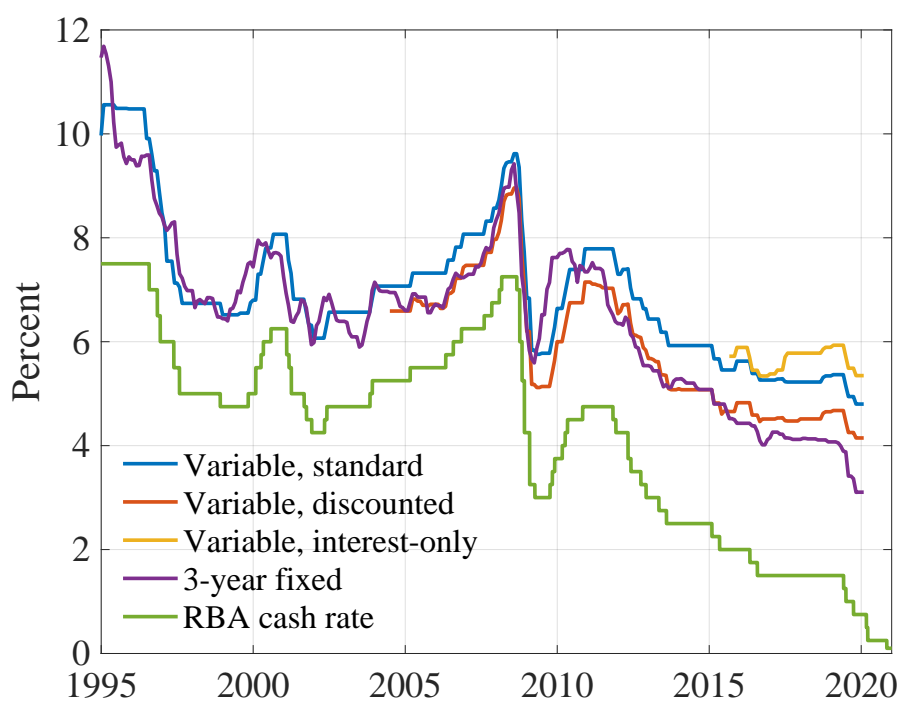

Source and note: Reserve Bank of Australia (2020).

\section{Conclusion}

The new results for Australian microdata presented here reject the "debt-overhang hypothesis" - that households cut back more on their spending in a crisis when they have higher levels of outstanding mortgage debt (Dynan, 2012). The results instead support the "spendingnormalization hypothesis" of Andersen, Duus, and Jensen (2016), what can also be called the "debt-financed overspending" hypothesis - that the correlation between high pre-crisis household indebtedness and subsequent spending falls during the crisis reflected high debt-financed spending pre-crisis and a return to normal spending during the crisis. As further discussed in Svensson $(2019,2020)$, this is consistent with the correlation reflecting debt-financed overspending through what Muellbauer (2012) calls the "housing-collateral household-demand" and Mian and Sufi (2018) the "credit-driven household demand" channel.

It follows that it was not high household indebtedness in itself that caused the fall in spending during the crisis in Australia, Denmark, and the UK. ${ }^{18}$ There were some highly indebted households that cut down their spending more than others did, but this is better explained by these households having before the crisis engaged in a mortgage-financed overspending relative to income. This overspending could not continue during the crisis, and spending fell.

At the same time, increased mortgage loans for consumption purposes contributed to

institutional features of the Australian mortgage market which imply that the relationship between interest rates and borrower cash flows is not as straightforward as suggested by the theory.

18 See also Broadbent (2019) and Kearns et al. (2020). 
many households being highly indebted. Mortgage financing of overspending thus caused both the fall in spending and to a certain extent the high indebtedness. This created a correlation between high indebtedness and subsequent consumption declines - but not a causal relationship between them.

It follows that high household debt-to-income ratios in themselves contain little or no information about risks of a spending fall associated with household indebtedness. This is in contrast to what seems to be taken for granted by macroprudential authorities in many countries, as well as by the international organizations that comment on countries' macroprudential policy. As discussed in Svensson (2019, 2020), in order to assess such risks, among other things, one needs to examine whether there is any evidence of an active housingcollateral channel and any mortgage-financed overspending of macroeconomic significancean aggregate debt-financed consumption boom, for example resulting in a low household saving rate. As Muellbauer (2012) emphasizes, the strength of the housing-collateral channel varies considerably between countries depending on differences in the structure of housing and mortgage markets as well as in customs and preferences. Furthermore, if there is significant housing-equity withdrawal, it matters whether this is used for consumption purposeswhether mortgages are effectively used as consumption loans - or for other purposes, such as home improvement, paying off expensive consumer loans, or investment in financial assets, including keeping a liquidity buffer.

These issues for Sweden and their relevance for Swedish macroprudential policy are further discussed in Svensson (2019, 2020).

It remains to test these hypothesis for other countries than Australia, Denmark, and the UK. I would not be surprised if rejection of the debt-overhang hypothesis and support for the debt-financed overconsumption hypothesis is a pretty general result.

\section{References}

Andersen, Asger Lau, Charlotte Duus, and Thais Lærkholm Jensen (2016), "Household Debt and Spending During the Financial Crisis: Evidence from Danish Micro Data," European Economic Review 89, 96-115, https://doi.org/10.1016/j.euroecorev.2016.06.006.

Australian Bureau of Statistics (2018), "Household Debt and Over-Indebtedness in Astralia," 6523.0 - Household Income and Wealth, Australia, 2015-16, Featured Article, Australian Bureau of Statistics, https://www.abs.gov.au/ausstats/abs@.nsf/Lookup/ by\%20Subject/6523.0 2015-16 Feature\%20Article Household\%20Debt\%20and\%20Overindebtedness $\% 20$ (Feature\%20Article) 101.

Broadbent, Ben (2019), "Debt Dynamics," speech at London Business School, January 23, 2019, Bank of England, https://www.bankofengland.co.uk/speech/2019/ben-broadbentspeech-at-london-business-school. 
Bunn, Philip, and May Rostom (2014), "Household Debt and Spending," Bank of England Quarterly Bulletin 2014 Q3 54(3), 304-315, https://www.bankofengland.co.uk/quarterlybulletin/2014/q3/household-debt-and-spending.

Bunn, Philip, and May Rostom (2015), "Household Debt and Spending in the United Kingdom," Staff Working Paper No. 554, Bank of England, https://www.bankofengland.co.uk/ working-paper/2015/household-debt-and-spending-in-the-uk.

Campbell, John Y., and N. Gregory Mankiw (1989), "Consumption, Income, and Interest Rates: Reinterpreting the Time Series Evidence," NBER Macroeconomics Annual 1989, 185-216, https://www.nber.org/chapters/c10965.pdf.

Carney, Mark (2020), "The Grand Unifying Theory (and Practice) of Macroprudential Policy," Speech at University College, London, on March 5, 2020, Bank of England, https://www.bankofengland.co.uk/speech/2020/mark-carney-speech-at-universitycollege-london.

DSS and Melbourn Institute (2018), "The Household, Income and Labour Dynamics in Australia (HILDA) Survey, GENERAL RELEASE 17 (Waves 1-17)," database, Department of Social Services and Melbourne Institute of Applied Economic and Social Research, ADA Dataverse, https://dataverse.ada.edu.au/dataset.xhtml?persistentId=doi: 10.26193/PTKLYP.

Dynan, Karen (2012), "Is Household Debt Overhang Holding Back Consumption?" Brookings Papers on Economic Activity Spring 2012, 299-344, https://www.brookings.edu/wpcontent/uploads/2016/06/2012a_Dynan.pdf.

Finansinspektionen (2017), "A Stricter Amortization Requirement for Households with High Loan-to-Income Ratios," Decision Memo FFFS 2017:23, Ref. 17-9236, December 11, 2017, Finansinspektionen-The Swedish Financial Supervisory Authority, https://www.fi.se/ en/our-registers/search-fffs/2016/201616/201723/.

Flodén, Martin, Matilda Kilström, Jósef Sigurdsson, and Roine Vestman (2018), "Household Debt and Monetary Policy: Revealing the Cash-Flow Channel," working paper, http: //www.matildakilstrom.com/wp-content/uploads/2016/01/FKSV_20180802.pdf.

Guren, Adam M., Arvind Krishnamurthy, and Timothy J. McQuade (2019), "Mortgage Design in an Equilibrium Model of the Housing Market," working paper, http: //people.bu.edu/guren/gkm_mortgage_design.pdf.

Hull, Isaiah (2017), "Amortization Requirements and Household Indebtedness: An Application to Swedish-Style Mortgages," European Economic Review 91, 72-88, https: //www.sciencedirect.com/science/article/abs/pii/S0014292116301507.

Kaplan, Greg, Kurt Mitman, and Giovanni L. Violante (2019), "The Housing Boom and Bust: Model Meets Evidence," Journal of Political Economy, forthcoming, https:/static1.squarespace.com/static/5d69437d65a29d0001ae6520/t/ 5daa58e5a6cdd33e2a9060e4/1571444967065/kaplan_mitman_violante_sep2019.pdf. 
Kaplan, Greg, Giovanni L. Violante, and Justin Weidner (2014), "The Wealthy Handto-Mouth," Brookings Papers on Economic Activity Spring 2014, 77-138, https:// www.brookings.edu/wp-content/uploads/2016/07/2014a_Kaplan.pdf.

Kearns, Jonathan, Mike Major, and David Norman (2020), "How Risky is Australian Household Debt?" Research Discussion Paper RDP 2020-05, Reserve Bank of Australia, https://www.rba.gov.au/publications/rdp/2020/2020-05.html.

La Cava, Gianni, Helen Hughson, and Greg Kaplan (2016), "The Household Cash Flow Channel of Monetary Policy," Research Discussion Paper RDP 2016-12, Reserve Bank of Australia, https://www.rba.gov.au/publications/rdp/2016/2016-12.html.

Mian, Atif, Kamalesh Rao, and Amir Sufi (2013), "Household Balance Sheets, Consumption, and the Economic Slump," Quarterly Journal of Economics 128(4), 1687-1726.

Mian, Atif, and Amir Sufi (2010), "Household Leverage and the Recession of 2007-2009," IMF Economic Review 58(1), 74-117.

Mian, Atif, and Amir Sufi (2011), "House Prices, Home Equity-Based Borrowing, and the US Household Leverage Crisis," American Economic Review 101(5), 2132-2156.

Mian, Atif, and Amir Sufi (2018), "Finance and Business Cycles: The Credit-Driven Household Demand Channel," Journal of Economic Perspectives 32(3), 31-58.

Muellbauer, John (2012), "When Is a Housing Market Overheated Enough to Threaten Stability," in Heath, Alexandra, Franck Packer, and Callan Windsor (eds.), Property Markets and Financial Stability, Reserve Bank of Australia, pages 73-105, https: //www.rba.gov.au/publications/confs/2012/pdf/conf-vol-2012.pdf.

Price, Fiona, Benjamin Beckers, and Gianni La Cava (2019), "The Effect of Mortgage Debt on Consumer Spending: Evidence from Household-level Data," Research Discussion Paper RDP 2019-06, Reserve Bank of Australia, https://www.rba.gov.au/publications/rdp/ 2019/pdf/rdp2019-06.pdf.

Reserve Bank of Australia (2012), Statement on Monetary Policy, November 2012, Reserve Bank of Australia, https://www.rba.gov.au/publications/smp/2012/nov/.

Reserve Bank of Australia (2020), "Statistical Tables, Indicator Lending Rates - F4; Housing Loans; Owner-Occupier," Statistical web page, Reserve Bank of Australia, https: //www.rba.gov.au/statistics/tables/xls/f05hist.xls.

Svensson, Lars E.O. (2016), "Amortization Requirements May Increase Household Indebtedness: A Simple Example," IMF Working Paper WP/16/83, International Monetary Fund, https://www.imf.org/external/pubs/ft/wp/2016/wp1683.pdf.

Svensson, Lars E.O. (2019), "Housing Prices, Household Debt, and Macroeconomic Risk: Problems of Macroeconomic Policy I," working paper, Stockholm School of Economics, https://larseosvensson.se/2018/12/16/housing-prices-household-debt-andmacroeconomic-risk-problems-of-macroprudential-policy-i/. 
Svensson, Lars E.O. (2020), "Macroprudential Policy and Household Debt: What is Wrong with Swedish Macroprudential Policy?" Nordic Economic Policy Review 2020, 111167, https://larseosvensson.se/2019/12/05/macroprudential-policy-and-household-debtwhat-is-wrong-with-swedish-macroprudential-policy/.

Svensson, Lars E.O. (2021), "High Household Debt-to-Income Ratios Did Hardly Cause a Larger Spending Fall during the Financial Crisis in the UK," working paper, Stockholm School of Economics, https://larseosvensson.se/2021/04/20/household-debt-overhangdid-hardly-cause-a-larger-spending-fall-during-the-financial-crisis-in-the-uk/. 


\section{Appendix}

\section{A Amortization}

This appendix shows how to introduce amortization into the simple model of debt-financed overconsumption. We start from (2.1),

$$
C_{t}=\mathrm{EI}_{t}-i_{t} D_{t-1}+\Delta D_{t}
$$

With amortization, we now have

$$
\Delta D_{t} \equiv D_{t}-D_{t-1}=-a_{t} D_{t-1}+R_{t}
$$

where $a_{t}$ satisfying $0 \leq a_{t}<1$ is the rate of mandated amortization (contracted or regulated) and $R_{t}$ denotes refinancing if $R_{t}>0$ and voluntary additional amortization if $R_{t}<0$.

The household is assumed to be subject to a loan-to-value constraint, if it wants to refinance,

$$
D_{t} \leq \alpha P_{t} \text { if } R_{t}>0
$$

Restricting the LTV constraint to apply only when there is refinancing implies the realistic property of LTV constraints that the household does not have to amortize more than the mandatory amortization if housing prices fall and cause the LTV constraint to be violated. (Again, there are no margin calls for mortgage debt, beyond the mandatory amortization.)

Again, because the household is constrained to consume less than it would prefer, it takes out the maximum possible mortgage - maximizes HEW - each year. If the LTV constraint is not violated at an unchanged debt level, the household will refinance to make or keep the LTV constraint binding. If housing prices have fallen so as to cause the LTV constraint to be violated, the household will reduce the debt level according to the mandated amortization,

$$
D_{t}= \begin{cases}\alpha P_{t} & \text { if } D_{t-1} \leq \alpha P_{t} \\ \left(1-a_{t}\right) D_{t-1} & \text { if } D_{t-1}>\alpha P_{t}\end{cases}
$$

By (2.6), disposable income excluding imputed rental income, $\mathrm{DIX}_{t}$, is given by

$$
\mathrm{DIX}_{t}=\mathrm{EI}_{t}-i_{t} D_{t-1}
$$

and the budget constraint can be written

$$
C_{t}=\mathrm{DIX}_{t}+\Delta D_{t}
$$

(Non-housing) consumption (spending) equals DIX plus the change in debt.

Figure A.1a shows the same example as in figure 2.1a, except that there is a $2 \%$ amortization rate. ${ }^{19}$ Nevertheless, the outcome is the same as in figure 2.1a without amortization. When housing prices rise and the LTV constraint is not violated, the household refinances to cover both the amortization and a net debt incease to keep the LTV ratio at the cap

\footnotetext{
19 The parameters and initial values are as in section $2, \alpha=85 \%, P_{0}=P_{1}=440$, and $D_{0}=\alpha P_{0}=374$, and $\mathrm{EI}_{t}=\mathrm{EI}=110$, and $i_{t}=i=4 \%$ for $t \geq 0$, with the addition of $a_{t}=a=2 \%$ for $t \geq 0$.
} 
Figure A.1: Housing prices, debt, LTV ratios, and consumption with amortization

a. Housing prices start to grow at $4 \%$ from year 1 but stay constant from year 10
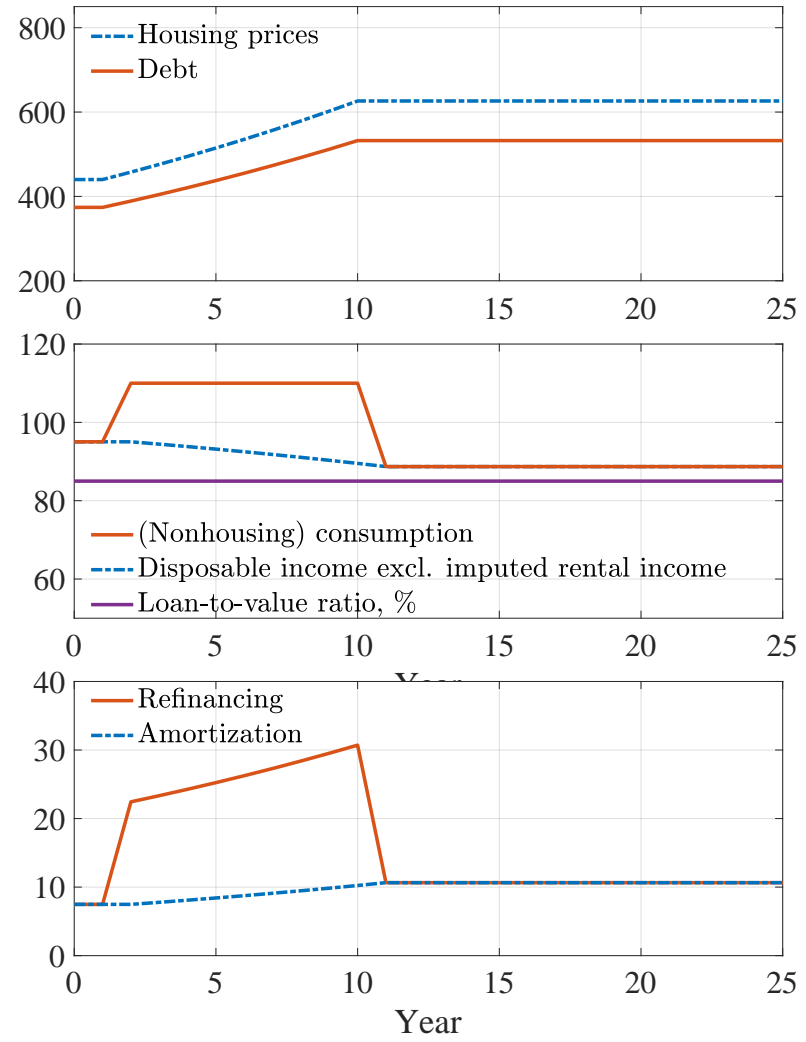

b. Housing prices start to grow at $4 \%$ from year 1, except for a drop by $25 \%$ in year 11
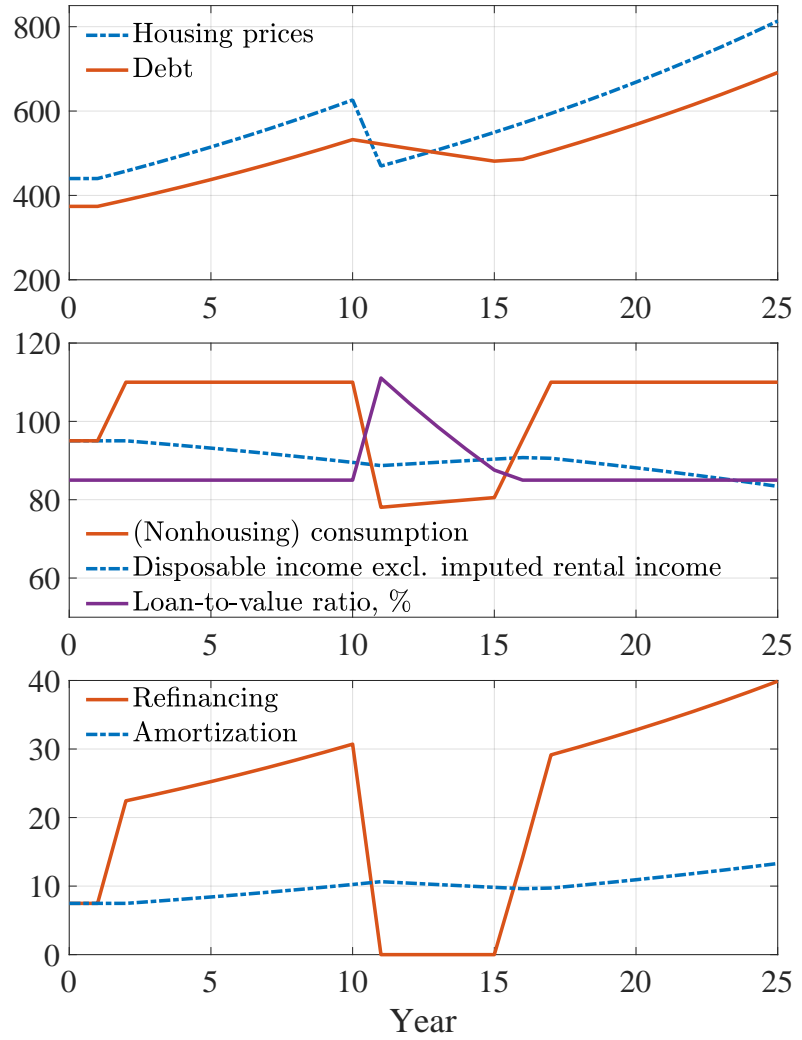

of $85 \%$. Again, the household can increase its consumption substantially above DIX from year 2. DIX is less than earned income by the interest payments. When debt rises, DIX falls further below earned income.

When prices stop growing, the household can no longer maintain the high and growing consumption, but it can still keep its mortgage constant at the binding LTV constraint by refinancing to cover the amortization. ${ }^{20}$

Figure A.1b shows the same example as in figure $2.1 \mathrm{~b}$, but with the addition of the mandatory amortization rate of $2 \%$. Here, when prices drop by $25 \%$ in year 11 and resume to grow at $4 \%$, the LTV constraint is violated for the years 11-15. This prevents refinancing, and the household has to reduce its consumption further, below DIX, to amortize $2 \%$ per year. Consumption therefore drops by a full $29 \%$ instead of by $19 \%$ in figure A.1a. The amortization reduces debt, which falls until year 15. Meanwhile, DIX and consumption rise a bit, due to the debt service falling a bit with lower debt. In year 16, the prices have risen and debt has fallen so much that LTV constraint is no longer violated, and the household can resume its refinancing and debt-financed overconsumption relative to DIX.

In figures A.1a and b, we can still interpret year 11 as a crisis year and year 10 as a pre-crisis year. The consumption change from year 10 to year 11 is in these examples by

\footnotetext{
20 See Hull (2017) and Svensson (2016) for further discussion of how refinancing or excess initial borrowing can neutralize the effect of mandatory amortization requirements.
} 
equation (2.1) given by

$$
C_{11}-C_{10}=\Delta C_{11}=\Delta \mathrm{EI}_{11}-i \Delta D_{10}+\left(\Delta D_{11}-\Delta D_{10}\right)
$$

Furthermore, for the example in figure A.1a, the right-hand side equals that of (2.8), so

$$
C_{11}-C_{10}=-i \frac{g}{1+g} D_{10}-\Delta D_{10}
$$

in figure A.1a, where we again use that that $\mathrm{EI}_{t}$ and $i_{t}=i$ are constant and that $i \Delta D_{10}=$ $i g D_{9}=i g D_{10} /(1+g)$, where $g$ is the constant growth rate of housing prices and debt up to year 10 . Furthermore, $\Delta D_{11}=0$, because refinancing in year 11 equals the amortization and keeps the debt level constant.

However, in the experiment in figure A.1b, there is no refinancing in year 11, so by (A.1) we have $\Delta D_{11}=-a D_{10}$, and instead of (A.5) we have

$$
C_{11}-C_{10}=-\left(i \frac{g}{1+g}+a\right) D_{10}-\Delta D_{10}
$$

With $i=g=4 \%$ and $a=2 \%$, on the right-hand side of (A.5) the coefficient of $D_{10}$ is only minus 0.0015, whereas on the right-hand side of (A.6) it is minus 0.0415, larger in magnitude, but still much smaller than the coefficient of minus 1 on $\Delta D_{10}$.

So, in these simple examples, also when there is mandated amortization, the consumption fall during the "crisis" overwhelmingly depends on the pre-crisis debt increase, $\Delta D_{10}$, not on the pre-crisis debt level, $D_{10}$. 